Alba Fedeli

\title{
The Qur'ānic Text from Manuscript to Digital Form: Metalinguistic Markup of Scribes and Editors
}

\section{Different Technologies and Similarities in Writing the Qur'ānic Text}

Texts necessarily embody and are expressed by different technologies that are available at different times and in diverse geographical and cultural areas. Thus, texts cannot exist divested of their material form and technology, factors which influence the idea of the text itself. ${ }^{1}$ The identity of any textual object but sacred texts in particular - thus seems to include fluidity and invariance, elements which would seem to be contradictory. ${ }^{2}$ With regard to the Qur'anic text, its digital (i.e., computational) encoding allows us to see the richness of the manuscript, in contrast to the fixed and static page of the printed Qur'ān. In fact, during an important time of change like the digital revolution, materiality becomes apparent to scholars who have to face manuscript variance in the new digital paradigm.

Mordenti suggests that a close consideration of pre-Gutenberg systems can shed light on the mechanisms of the post-Gutenberg context. ${ }^{3}$ Indeed, the two non-Gutenberg contexts of manuscript culture and digital texts/objects share and overlap at many points and, possibly, the perspective suggested by Mordenti is reciprocal. Indeed, manuscript texts and their mechanisms can be used as a lens

1 Raul Mordenti, "Parádosis. A proposito del testo informatico," Atti della Accademia Nazionale dei Lincei. Classe di Scienze Morali, Storiche e Filologiche, Memorie, Serie IX, 28 (2011): 623-91.

2 Dino Buzzetti, "Biblioteche digitali e oggetti digitali complessi: Esaustività e funzionalità nella conservazione," in Archivi informatici per il patrimonio culturale, Convegno internazionale organizzato dall'Accademia Nazionale dei Lincei in collaborazione con ERPANET e la Fondazione Franceschini (Roma: Accademia Nazionale dei Lincei, Bardi Editore, 2006): 41-75, 51-53, i.e. "Il testo è un oggetto mobile e immutabile ad un tempo, mobile per la sua variabilità e immutabile per la sua invarianza."

3 Mordenti, "Parádosis.”

Note: I owe a great deal to the inspiring comments I received from Dino Buzzetti about digital encoding, markup, and other puzzling questions. I also thank him heartily for his time in discussing new ideas in my manuscript reading and encoding and his generosity in sharing some helpful references with me. 
for understanding digital texts, but the latter horizon can also shed light on the pre-Gutenberg system. Thus, for example, a deep comprehension of diacritical signs in scripts can disclose subtle mechanisms behind the concept of markup in a digital environment. However, in a reciprocal perspective, tools with a diacritical function developed in early manuscripts can be understood through the lens of markup theory in digital editing.

The materiality of manuscripts on which scholars are forced to reflect when digitally encoding Qur'ānic manuscript texts must also be understood in the sense of the physicality of the technology used in the process of writing. A challenging example of such materiality is the ambiguity of the (complex) writing systems in early Qur'ānic manuscripts and the assumptions embedded in our editing and reading activities because of our typographical mindset. ${ }^{4}$ In digital encoding, scholars cannot leave ambiguous examples and rely on the "tolerance and perspicacity of the readers"5 because the simple - binary - system of the machine cannot admit tolerance and perspicacity.

Thus, the aim of the present contribution is twofold. First, it describes several elements of the materiality and technology of the manuscript form of the Qur'anic text. Second, it suggests reflection on such technology on the part of the editor during the act of digitally encoding the manuscript form, in light of the hypothesis that the computational/digital text has many similarities with the handwritten text of the manuscript tradition and appears to be far from the rigid, fixed, static and closed text of the printed dimension. The idea of a fixed and static text imposed by the Gutenberg revolution is particularly evident in the history of the Qur’ānic printed text.

4 See, for example, Monella and his five Gutenbergian assumptions, connected with the concept of standardization, i.e. standard alphabet, standard graphic system, standard spelling, standard sequentiality and lastly, the correspondence of one grapheme and one alphabeme, in Paolo Monella, "Many Witnesses, Many Layers: The Digital Scholarly Edition of the Iudicium Coci et Pistoris (Anth. Lat. 199 Riese),” in Digital Humanities: Progetti Italiani Ed Esperienze Di Convergenza Multidisciplinare, Atti Del Convegno Annuale Dell'Associazione per l'Informatica Umanistica e La Cultura Digitale (AIUCD) Firenze, 13-14 Dicembre 2012, ed. Fabio Ciotti (Roma: Sapienza Università Editrice, 2014): 173-206.

5 D’Arco Silvio Avalle, “I canzonieri: definizione di genere e problemi di edizione," in La critica del testo. Atti del Convegno di Lecce, 22-26 ott. 1984 (Roma: Salerno Editrice, 1985): 363-82 (380). 


\section{A Long Way to a Static Text, Materialized in Printed Leaves}

The encounter between the Qur'ānic text and the movable type printing press was a very slow process that lasted centuries. In the case of Muslims, it passed through the mediation of lithographic technology which allowed for the copying of manuscript texts, while Europeans ventured into printing the Qur'ānic text from the sixteenth century without considering the cultural implications of the new technology.

A formal interdiction to ban the production as well as the trade of printed texts of the Qur'ān was decreed in the territories of the Ottoman Empire. The ban lasted from the first attempt at producing printed copies of the Qur'ān in Europe in the sixteenth century with the business disaster of Paganino de' Paganini, until the decision in the 1870 s to produce a lithographic edition of the calligraphic copy of the famous master Hafız Osman. After the introduction of printing, European publishers had ventured into producing Arabic editions of the Qur'ānic text intended for a Muslim audience, looking for a possible successful market in the Muslim world. Thus, in 1537/1538, Paganino de' Paganini printed the first text of the Qur'ān, but it was a business disaster. ${ }^{6}$ The unique existing copy was discovered in the library of the Venetian island of San Michele a few decades ago. Its reappearance confirmed the authenticity of this venture and led to the formulation of diverse hypotheses about the existence of a unique copy. ${ }^{7}$ The Ottoman sources clarify the mystery of de' Paganini's surviving copy as all the other copies that arrived in Istanbul were confiscated and destroyed by the Ottoman authorities, because the importation of printed books in the Arabic script - Qur'annic as well as non-Qur'ānic - was prohibited. Paganini was probably saved from being executed thanks to the intervention of a Venetian ambassador, according to the account in the Colloquium heptaplomeres by Jean Bodin (1530-1596). ${ }^{8}$

6 It is likely that it was also a disaster in terms of the aesthetic results in reproducing the Arabic alphabet with moveable type.

7 See Angela Nuovo, Alessandro Paganino (1509-1538) (Padova: Editrice Antenore, 1990), 107-31 (chapter on "Il Corano").

8 The story of the prohibition and subsequent destruction of de' Paganini's copies has been reconstructed in M. Brett Wilson, Translating the Qur'an in an Age of Nationalism: Print Culture and Modern Islam in Turkey (Oxford: Oxford University Press in association with The Institute of Ismaili Studies, 2014), 32ff. The reference to the ban on trading Paganini's printed Qur'āns in the Colloquium heptaplomeres de rerum sublimium arcanis abditis is very interesting: "il auroit esté puny de mort: mais il en fut quitte pour la perte de ses exemplaires qui feurent bruslez et pour sa main droicte qui luy fut coupée parce que ce livre estoit tout remply de fautes." See Colloque 
Bodin explicitly mentioned the presence of mistakes in the copies printed by Paganino (i.e., "infinitis erroribus scatebat") as the reason that led the Ottoman authorities to destroy these copies. In fact, the key point in accepting the new technology was its legitimization from the 'ulam $\bar{a}$ ' who had to be involved in the checking activity and approval of the correctness of the text, thus confirming the chain of transmission of the text. The printing of the Qur'anic text as a European enterprise lacked that lineage of transmission that is essential in Islam. ${ }^{9}$ Thus, in the Ottoman Empire, the embargo imposed on printed copies of the Qur'ān consequently made the calligraphic Qur'ān in its manuscript form the only licit form of the sacred book. The compromise of the photolithographic - though mechanical - reproduction of a handwritten artefact executed according to traditional skills and knowledge allowed the shift from manuscript culture to the emergent printed dimension. The control over the accuracy of the text by religious authorities who can guarantee its lineage in a new technology is a phenomenon that has recently re-emerged in the current period of the shift to the electronic form of the Qur'ānic text which is in circulation on the Web. ${ }^{10}$

entre sept scavans qui sont de differens sentimens: des secrets cachez des choses relevées, traduction anonyme du Colloquium heptaplomeres de Jean Bodin (manuscrit français 1923 de la Bibliothèque Nationale de Paris), eds. François Berriot, Katharine Davies, Jean Larmat, Jacques Roger (Genève: Librairie Droz, 1984): 352. The reference to the possible presence of mistakes in the printed form of the sacred text is a key point in the history of the transmission of the text embodied through different technologies. See for example the discussions and efforts related to having a text free from mistakes in the online copies of the Qur'ānic text.

9 Wilson, Translating the Qur'an, 37, 40.

10 See for example the proceedings of the Conference held in 2013 on information technology used for the electronic text of the Qur'ān, i.e. Juan E. Guerrero ed., Proceedings of 2013 Taibah University International Conference on Advances in Information Technology for the Holy Quran and Its Sciences, NOORIC 2013 (Piscataway, NJ: The Institute of Electrical and Electronics Engineers, Inc., Conference Publishing Service, IEEE Service Center, 2015). In the proceedings, there are proposals for detecting and authenticating Qur'ānic verses by security systems based on authentication agencies such as Al-Azhar or the King Fahd Quran Complex, e.g. Thabit Sabbah and Ali Selamat, "A Framework for Quranic Verses Authenticity Detection in Online Forum," in Proceedings of 2013 Taibah University International Conference on Advances in Information Technology for the Holy Quran and Its Sciences, NOORIC 2013, ed. Juan E. Guerrero (Piscataway, NJ: The Institute of Electrical and Electronics Engineers, Inc., Conference Publishing Service, IEEE Service Center, 2015): 6-11; Izzat M. Alsmadi, “Techniques to Preserve the Integrity of the Electronic Versions of the Nobel Quran,” in Guerrero, Proceedings of 2013 Taibah University International Conference, 52-56 and Mostafa G.M. Mostafa and Ibrahim M. Ibrahim, "Securing the Digital Script of the Holy Quran on the Internet," in Guerrero, Proceedings of 2013 Taibah University International Conference, 57-60. 


\section{The Material Embodiment of Early Qur'ānic Manuscripts}

Material properties can embody the use and function of a text, sometimes assuming a sociological and symbolic meaning (for more on this, see the contributions from Suit and Anderson in the present volume). The peculiarities of the textual environment express and participate with the textual meaning. ${ }^{11}$ Thus, for example, the codex is the format par excellence of the sacred text of Islam, the muṣhaf (pl. mașāhif), which is defined as a collection of written leaves placed and contained between two covers ${ }^{12}$ and materialized in the surviving remains of a codex form attested in (fragmentary) leaves, quires and groups of quires dating from the first centuries of Islam. A reflection on the technology of the early manuscript form of the Qur'ānic text concerns mainly its codex form, its parchment writing surface, and its layout.

\subsection{Writing Material Surface: Parchment, Papyrus, and Paper}

The codex format, already known in pagan Rome, replaced and contrasted socially with the previous papyrus roll in the transcription of the Jewish and Christian sacred scriptures (see the chapters from del Barco and Outhwaite in the present volume). ${ }^{13}$ By contrast, in the written transmission of the Qur'ānic text,

11 Jonathan Walker, "Reading Materiality: The Literary Critical Treatment of Physical Texts," Renaissance Drama 41 (2013): 199-232 (201).

12 al-Farrā' considered the word muṣhaf as a passive participle, i.e. "which has been caused to contain written sheets between two end-covers"; see John Burton, "Muṣhaf" in Encyclopaedia of Islam, 2nd ed., eds. C.E. Bosworth, E. van Donzel and W.P. Heinrichs and Ch. Pellat (Brill: Leiden, 1993): 7:668-69. As regards the format of the leaves contained bayna lawhayni, see Abū Bakr Ibn Abī Dāwūd, Kitāb al-Mașāhịf, ed. Arthur Jeffery, 5 (Arabic section in Arthur Jeffery, Materials for the History of the Text of Qur'ān. The Old Codices, The Kitāb al-Mașāhif of Ibn Abī Dāwūd together With a Collection of the Variant Readings from the Codices of Ibn Ma'sūd, Ubai, Alī, Ibn 'Abbās, Anas, Abū Mūsā and other early Qur'ānic authorities which present a type of text anterior to that of the canonical text of 'Uthmān [Leiden: Brill, 1937]).

13 Maria Luisa Agati, The Manuscript Book: A Compendium of Codicology, trans. Colin W. Swift (Roma: L'Erma di Bretschneider, 2017 [2009]): 129-35, mentioning Cavallo in relation to the sociological and cultural reasons for the use of the codex form in the transmission of the Christian texts. See also David C. Parker, An Introduction to the New Testament Manuscripts and Their Texts (Cambridge: Cambridge University Press, 2008), 19, on the codex as the overwhelmingly predominant format in Christianity. 
the codex is considered the original and first attested format. The first copies of mașāhif produced from the seventh century CE were made of parchment leaves obtained from animal skins processed using a special treatment. As parchment is generally considered a very expensive material, the production of copies of the Qur'ānic text is consequently interpreted as a non-personal activity meant for public use and proposing a common visual identity of the written sacred text. However, there is no evidence for suggesting the actual price of parchment leaves or their usage. An interesting aspect of materiality and its cultural implications is the abundance of skins and hides of animals because of the ritual sacrifice of animals whose meat was to be shared with the poor. Moreover, the skins and hides of those sacrificed animals had to be sold and the sum thus realized had to be donated in charity. ${ }^{14}$ The surplus of skins during the ritual sacrifice of animals and the order to give the skins or their proceeds to charity implies that large quantities of skins were available to be used in certain periods of the Islamic year, including the use of leather for parchment. ${ }^{15}$

Parchment was the preferred material for writing the Qur'ānic text in the first four centuries of Islam, while papyrus was reserved for documentary materials in the Islamic world. When used for writing pieces of the Qur'ānic text, the latter material embodies the function of talismans, amulets and personal use of the

14 Șaḥīh al-Bukhārī, Book al-Ḥağğ, chapter al-Ğilāl li-l-budn (Beirut: Maktaba Aț-Taqafiya), vol. 2, no. 289. In bn Mağāh, independently from the sacrifice, it is mentioned that the skin of an animal must be used even when animals die from natural causes (Muhammad "commanded that use should be made of the skins of dead animals, if they were tanned") in Ibn Mağāh, Sunan Ibn Mağāh, Book al-Libās, chapter 25, ed. Muḥammad Fu'ād 'Abd al-Bāqī (al-Qāhira: Dār Iḥyā' al-Kutub al-'Arabiyya, 1952), 1193-94.

15 As regards the use of skins and hides, see for example Shlomo Dov Goitein, A Mediterranean Society: The Jewish Communities of the Arab world as Portrayed in the Documents of the Cairo Genizah. Vol. 1, Economic Foundations (Berkeley: University of California Press, 1967): 111-12; Ahmad Y. al-Hassan and Donald R. Hill, Islamic Technology. An Illustrated History (Cambridge: Cambridge University Press, 1986 [1992]): 199-200 (leather products). Maya Shatzmiller, Labour in the Medieval Islamic World (Leiden: Brill, 1994) lists a series of professions related to the manufacturing of skins and hides as leather and parchment (112-13, 230-32), e.g. the ğalla d, whose use is attested in Iraq, Egypt and Syria in the ninth to the eleventh century to indicate the "leather worker, leather merchant, worker and/or seller of hides"; the muğallid attested in Iraq since the 8th century to mean the leather worker or bookbinder; and the ruqūqu, i.e. the polisher of skins, parchment maker (in Egypt in the tenth to the thirteenth century). 
Qur'ānic text. ${ }^{16}$ An exception is represented by the recently discovered Hamburg papyrus, which is a quire of seven papyrus bifolia. ${ }^{17}$

Papyrus is often thought to be more fragile than the stronger parchment. However, because of the durability of parchment, the ability to remove its ink, and its ability to be reused/modified, parchment has become associated with temporary documents and the modifiability of non-destroyable sacred text. ${ }^{18}$ Thus, Grohmann reported that the caliphs' correspondence was preferably written on papyrus as it is impossible to cancel the script by erasure or even to change it without completely destroying the papyrus. ${ }^{19}$ Indeed, there are examples of reuse of parchment writing materials in Qur'ānic palimpsests. ${ }^{20}$ This peculiar form of recycling concerns Qur'ānic leaves reused to write new Qur'ānic leaves, retaining the original size and vertical format, like in the case of the Sanaa palimpsest; Qur'ānic leaves reused together with several different text for writing Christian Arabic texts destroying the original size and/or vertical format like the Sinai palimpsest; and, lastly, Coptic leaves reused for writing Qur'ānic text, as recently discovered. ${ }^{21}$

In the central area of the Islamic world, parchment was still in use in the tenth century but was gradually replaced by paper, while in the Muslim West, manuscript copyists continued to write on parchment until the fourteenth century and

16 For example Papyrus Mingana 107, Papyrus Duke inv.274 and Papyrus Utah inv.342 show traces of folding to take the shape of small square talismans with amalgams of Qurānic text; see Alba Fedeli, Early Qur'ānic Manuscripts, their Text, and the Alphonse Mingana Papers Held in the Department of Special Collections of the University of Birmingham (PhD thesis, Birmingham: University of Birmingham, 2015), 135-37, 336-40. See also the recent work by Andreas Kaplony and Michael Marx, eds., Qur'än Quotations Preserved on Papyrus Documents, 7th-10th Centuries And the Problem of Carbon Dating Early Qur'āns (Leiden: Brill, 2019).

17 The papyrus quire P.Hamb.arab. 68 of the Staats- und Universitätsbibliothek Hamburg is a single quire consisting of seven papyrus bifolia, each page measuring about $20.2 \times 16 \mathrm{~cm}$ in a landscape (almost squared) format, presented by Mathieu Tillier and Naïm Vantieghem at the series of the Colloques at the College de France, i.e. Le Coran dans l'histoire culturelle et intellectuelle de Fusțăt entre les VIIe et Xe siècles, in June 2018. Images of the Hamburg quire papyrus are available among the digitised collection online at https://digitalisate.sub.uni-hamburg. de/handschriften.html (the persistent url being https://resolver.sub.uni-hamburg.de/kitodo/ HANSh4089).

18 See Thomas Schmidt, “Greek Palimpsest Papyri: Some Open Questions” in Proceedings of the 24th International Congress of Papyrology (Helsinki, 2007).

19 Adolf Grohmann, From the World of Arabic Papyri (Cairo: Al-Maaref Press, 1952), 23.

20 The reuse of protocols on papyrus cannot be considered a proper palimpsesting process, as the ink of the first layer was not cancelled. Rather, in this form of recycling, the strategy was to use the empty spaces of the protocol.

21 Paper presented by Eléonore Cellard, "From Coptic to Arabic: A New Palimpsest for the History of the Qur'ān in Early Islam” at the annual IQSA Conference, Denver November 2018. 
perhaps even later. ${ }^{22}$ The replacement of parchment is not only evident from the number of paper codices as opposed to parchment codices, but evidence also comes from documents about Islamic social and economic activity. In fact, in her analysis of labour activities in the Medieval Islamic world, Shatzmiller observed that occupations employed in producing leather goods formed ten percent of the labour force in the Islamic city during the first three centuries of Islam but declined to nine percent after this first period, and suggests a possible reason for this decline was the introduction of paper and the elimination of parchment as a writing material. ${ }^{23}$

\subsection{Form: Codex and Roll}

As regards the technical format of the written object, it is worth noting that there are extant examples of rolls (rotulus) of the Qur'ānic text kept at the Museum of Turkish and Islamic Arts (TIEM) in Istanbul. These are forty-four Qur'ānic rotuli transferred from Damascus to Istanbul after the 1893 fire at the Great Mosque of Damascus. They are dated from different periods and written in different writing styles and on both papyrus (ten rotuli) and parchment (thirty-four rotuli). In her detailed description of the Damascus Qur'ānic rotuli, Ory observed the apologetic intention of the content of their Qur'ānic text; this includes, for example, exhortation to convert Jewish people, proclamation of the unity and omnipotence of God, truth of the new message and its connections with Abraham and the prophets, announcement of the Day of Judgement, the punishment of disbelievers, and the reward of righteous believers. Thus, the apologetic nature of the Qur'ānic rotuli mirrors the specific interests of Muslim scholars in seventh to twelfth century Damascus, around the Great Mosque. ${ }^{24}$

It is interesting to note that in the ecclesiastical tradition of the Latin West, the liturgical rotuli are dated from the eighth century, and the Greek world had probably already been using liturgical rolls in a variety of offices and ceremonies from the fifth-sixth century onward, until the fifteenth century. The fact that Greek rotuli are not decorated while the Latin ones are sumptuously illustrated mirrors a development of the Latin roll as an authentic symbol of power, although there is another hypothesis that explains the richness in illustrating rolls as an

22 François Déroche, “Codicology,” in Encyclopaedia of Islam Three, eds. Kate Fleet, Gudrun Krämer, Denis Matringe, John Nawas, Everett Rowson (Brill: Leiden, 2017): 1:26-39.

23 Maya Shatzmiller, Labour in the Medieval Islamic World (Leiden: Brill, 1994), $231-32$.

24 Solange Ory, "Un nouveau type de muṣhaf: inventaire des corans en rouleaux de provenance damascaine, conservés à Istanbul,” Revue des Etudes Islamiques 33 (1965/1966): 87-149 (146-49). 
instrument for transmitting certain messages to the illiterate masses, that is, for illustrating the text and, in a few cases, for adapting the texts to musical formulae. ${ }^{25}$ The Qur'ânic rotuli with possibly apologetic purposes do not seem to share any of the doctrinal instruments of propaganda expressed by the Latin roll, while its format (vertical rotulus against the horizontal volumen) is completely different from the typical Jewish scroll. The Qur'anic rotulus has more in common with the roll of the Eastern tradition, devoid of decoration and illustration. ${ }^{26}$

Dying of parchment is another element of the materiality of sacred texts which assumes a symbolic meaning residing in an interplay between neighbouring cultures and traditions. Thus, the famous blue Qur'ān leaves (of a codex) have been interpreted as a counter-project to the Greek and Latin purple manuscripts of imperial rank. Recently, D’Ottone has proposed that the blue Bible of Cava written in the north of Spain at the beginning of the ninth century is perhaps a competitive model for the blue Qur'ān leaves, possibly commissioned by an Umayyad patron in Spain in the context of the local production of the Christian sacred text on dyed parchment. ${ }^{27}$

\subsection{Layout}

The codex format - or at least its leaves and quires - was the original and dominant shape and arrangement of the written transmission of the Qur'ānic text, with traces that reveal a possible influence from other scribal traditions. The prevalent vertical format and single column arrangement are inscribed in what George defined as the visual landscape of Late Antiquity, as they match visual arrangement of Greek, Syriac, Christian Palestinian Aramaic, and Ethiopic manuscripts. ${ }^{28}$ A striking element in the main format of early Qur'ānic manuscripts is their relatively monumental size, which contrasts with the smaller format of the objects of the neighbouring traditions. Such large sizes might indicate possible cultural and political implications, intentionally marking the distinct status of the Qur'ānic text in opposition to the codices of the Christian sacred text.

25 Agati, The Manuscript Book, 126-28.

26 It is worth mentioning an exception that can be connected with the blue Qur'ān, i.e. the eleventh century Greek rotulus Borg.gr.27 of the Vatican Library, with its parchments dyed in red and light blue and written in gold and silver letters with the liturgy of John Chrysostom in the new Constantinople redaction. Agati, The Manuscript Book, 128.

27 Arianna D'Ottone, “The Blue Koran: A Contribution to the Debate on Its Possible Origin and Date,” JIM 8 (2017): 127-43.

28 Alain George, The Rise of Islamic Calligraphy (London and Beirut: Saqi Books, 2010), 40-49. 
A further element of the layout of a few very early Qur'ānic manuscripts is the absence of margins. The lines of script tend to occupy the entire surface of the writing material independently of the density of the script (i.e. dense or sparse script), suggesting that the argument of the exploitation of expensive materials is unfounded. The leaves of the codex Parisino-petropolitanus as observed by Déroche, ${ }^{29}$ and the manuscript whose leaves are scattered in Birmingham (Mingana Isl.Ar.1572b), St. Petersburg (NLR Marcel 17) and Doha (MIA MS 67), show examples of the absence of margins. A seemingly similar situation belongs to the Jewish community as expressed in the Cairo Geniza. In fact, in the Jewish documents on parchment, the four edges were not trimmed and the natural curves were initially left, especially on the right and lower edges, while at a second stage these irregular blank spaces of parchment were trimmed off. ${ }^{30}$ In the case of the layout of the Qur'ānic leaves mentioned above, the margins were not trimmed off and the script was adjusted to the irregular shape of the parchment material. The terminology designating the margins (hāšiya, hāmiš, and țurra) was also used to indicate the content of the matter placed in the margins as scholia and glosses. ${ }^{31}$ In fact, space is physically necessary to admit the insertion of annotations, and the space around the text block is the ideal repository for such amendments and comments to the text. Thus, the absence of margins in early Qur'ānic manuscripts may lead to the suggestion that the writing material's surface was totally used so as not to admit space for comments or changes to the text. However, this argument does not seem to be convincing, as the early artefacts turn out to be a repository of amendments and annotations. Moreover, even in later manuscripts featuring a well-organized and ordered use of script and space with generous margins, the expression, for example, of alternative readings is assigned to the space of the writing block by means of a colour-coded diacritic system rather than in the

29 François Déroche, La transmission écrite du Coran dans les débuts de l'islam: Le codex Parisinopetropolitanus (Leiden: Brill, 2009), 28-29 ("dès le départ la copie a occupé au maximum la surface disponible sur le feuillet”).

30 Shlomo Dov Goitein, A Mediterranean Society: The Jewish Communities of the Arab World as Portrayed in the Documents of the Cairo Genizah. Vol. 2, The Community (Berkeley: University of California Press, 1971), 232.

31 Adam Gacek, Arabic Manuscripts: A Vademecum for Readers (Leiden: Brill, 2009), 157 (s.v. "Margins"); François Déroche ed., Islamic Codicology: An Introduction to the Study of Manuscripts in Arabic Script, trans. Deke Dusinberre and David Radzinowicz (London: Al-Furqān Islamic Heritage Foundation, 2005-2006): 177-78 (“Margins”). On ḥāšiya, i.e. the supergloss, as a subgenre of $t a f s i \bar{r}$, see for example the enlightening article by Walid A. Saleh, "The Gloss as Intellectual History: The Ḥāshiyahs on al-Kashshāf," Oriens 41 (2013): 217-59. 
margins. ${ }^{32}$ Whatever reason lies behind the absence of margins, early Qur'ānic manuscripts still had space to host later additions, changes, amendments, annotations, and - using an ante litteram term - to host a markup system of the writing system and its code.

Describing the metalinguistic markup of scribes and thus the similarities between (a) the manuscript textual environment interpreted in light of (b) the digital encoding perspective, necessitates mentioning briefly a few basic features of the two elements.

\section{The Textual Environment of the Manuscript}

The physicality of the script's conditions concerns mainly two key aspects: the mechanism of the bare consonantal skeleton of the Arabic writing, and the markers for indicating the subdivision of the Qur'ānic text - both aspects are considered in connection with the phenomenon of the (alternative) readings of the text.

\subsection{Diacritics}

The Arabic script's system is based on the writing of its essential consonantal skeleton, which is composed of homograph base letters that can be distinguished by means of diacritics. Similarly, the consonantal skeleton can be differentiated by means of diacritics that mark mainly vowel signs.

These two sets of diacritic markers emerged in two distinct stages. The first markers used to disambiguate homograph letters (i.e., $i$ ( $\breve{g} \bar{a} m$ ) are attested in the earliest stages of the development of the Arabic script in the pre-Islamic period. I' $\breve{g} \bar{a} m$ diacritics are attested in documents such as the one-word Arabic inscription engraved in wood found in a Byzantine church in Petra, dated to the sixth

32 On the parallel situation in New Testament manuscripts facing the problem of restricted space at their disposal for inserting annotations in the margins, Parker has interestingly commented about the possible connection between the annotation to the Biblical text as interlinear or marginal notes and the gradual evolution toward the text's increasing stability when the annotation/commentate in proper commentaries made alternative renderings no longer necessary. See David C. Parker, Textual Scholarship and the Making of the New Testament (Oxford: Oxford University Press, 2012), 41-42. Parker's hypothesis leads to an exploration of whether Qur'ānic manuscripts show a higher degree of text stability in correlation with the opportunity to commentate on the text in separate works. 
or the beginning of the seventh century $\mathrm{CE}^{33}$; the inscription of Zuhayr in Northern Saudi Arabia, dated $24 \mathrm{AH} / 644 \mathrm{CE}^{34}$; and in papyrus PERF 558 from Egypt, dated $22 \mathrm{AH} / 642 \mathrm{CE} .{ }^{35}$ Early Qur'ān manuscripts from the seventh century have $i ` \breve{g} \bar{a} m$ diacritics executed in a stroke-like shape, while later they developed a more rounded shape. Early Arabic documents are not fully supplied with complete diacritic pointing, and previous scholarship has proposed some possible explanations for their distribution and motivation. For example, Kaplony observed that diacritics in a corpus of Arabic papyri mainly occur in specific environments, such as marking affixes and particles, thereby distinguishing grammatical categories similarly to the function of the Syriac dotting system. ${ }^{36}$

The second set of diacritic markers (i.e., naqt) is used to indicate mainly vowels as well as vowels in connection with nunation as the final ending of words, the hamza sign, and liaison between two words. Vowel diacritics were executed in a rounded dot-like shape placed above, below or after a certain letter to indicate respectively /a/, /i/, and / $\mathrm{u} /$ vowels. Vowel dots appear already in the early eighth century, mainly in Qur'ānic manuscripts, and were rarely used in non-Qur'ānic Arabic papyri. ${ }^{37}$ Similar to the use of $i$ ' $\breve{g} \bar{a} m$ diacritics, vowel dots are placed inconsistently in early Qur'ānic manuscripts from the eighth and ninth centuries. By contrast, this system of dots appears to be fully developed in manuscripts from the tenth and eleventh centuries. Consequently, Arabic vowel dots have been explained primarily through the lens of descriptions in Islamic sources from the tenth-eleventh centuries CE. ${ }^{38}$ Recently, Muehlhaeusler focussed on

33 Omar Al-Ghul, "An Early Arabic Inscription from Petra Carrying Diacritic Marks," Syria 81 (2004): 105-18.

34 'Ali Ibn Ibrahim Ghabban and Robert Hoyland, "The Inscription of Zuhayr, the Oldest Islamic Inscription (24 AH/AD 644-645), the Rise of the Arabic Script and the Nature of the Early Islamic State," Arabian Archaeology and Epigraphy 19 (2008): 210-37.

35 Alan Jones, "The Dotting of A Script And The Dating Of An Era: The Strange Neglect of PERF 558," Islamic Culture 72.4 (1998): 95-103.

36 Andreas Kaplony, "What are those Few Dots for? Thoughts on the Orthography of the Qurra Papyri (709-710), the Khurasan Parchments (755-777) and the Inscription of the Jerusalem Dome of the Rock (692)," Arabica 55 (2008): 91-112.

37 Geoffrey Khan, Arabic Papyri: Selected Material from the Khalili Collection (London and Oxford: The Nour Foundation, Azimuth Editions and Oxford University Press, 1992), 44. Khan observed three traces of old vocalization with dots, suggesting that the case of two vowel-dots in a word's internal position could be "a loan from Syriac before the later system of Arabic vocalisation became stabilised."

38 Dutton has investigated the use of coloured dots in some manuscripts; see Yasin Dutton, "Red Dots, Green Dots, Yellow Dots and Blue: Some Reflections on the Vocalisation of Early Qur'anic Manuscripts - Part I,” JQS 1 (1999): 115-40 and Part II, JQS 2 (2000): 1-24. Similarly, Cellard has studied the system of dots attested in some Qur'ānic fragments from the 8th century 
reading marks, distinguishing between disambiguating signs (i $i \breve{g} \bar{a} m$-diacritics and vowel dots) and syntactical or phonological markers. He observed that "the Arabic writing system is set up to consider each semantic element in isolation [...] and without regard for actual pronunciation," thus assigning to diacritical signs the function of compensating for this lack. ${ }^{39}$ Muehlhaeusler's conclusions are similar to Kaplony's hypothesis that diacritic dots mark grammatical categories. ${ }^{40}$

One of the main developments in the diacritic system of the Arabic script was the addition of a colour-based code which aimed at encoding readings from the perspective of alternative versus main readings. Basically, in the fully developed vowel-dot system, a bare consonantal skeleton like /T H R Ğ W N/ was furnished by $i$ ' $\breve{g} \bar{a} m$ diacritics in the shape of strokes that made explicit the reading of its possible homograph base letters to be read as $\mathrm{T} H \mathrm{G} \breve{G}[\mathrm{~N}]$ (fig. 1 and 2). This was also specified by vowel-dots according to the encoding system of positioning them above, below, and after the base letter. Thus, T H R Ğ W N could be specified through the vowel-dot system, based on a position code and added in red ink, expressing the reading tuhrağūna in Q. 30:19 (fig. 3). The level of red vowel dots could be further enhanced by placing another level of vowel dots in a different colour, for example in green ink (fig. 4). Thus, the bare consonantal skeleton at the red vowel-dot level indicates e.g. tuhrağūna (i.e., "you will be brought out," which is the reading of the majority of the readers) while at the green vowel-dot level the same consonantal skeleton displays a further reading, e.g. tahruğūna (i.e. "you will leave," which is the reading for example of al-Kisa'ī). ${ }^{41}$

The system developed for annotating simultaneously multiple readings in Qur’ānic manuscripts by means of different colours shares, to a certain degree,

to the mid-9th century. She mainly investigated the variation between hamza, imāla, and third person pronominal suffixes ( $h u$ and hum) in comparison with the description of these features in the early Islamic scholarly literature, see Eléonore Cellard, "La vocalisation des manuscrits coraniques dans les premiers siècles de l'islam," in François Déroche, Christian J. Robin and Michel Zink, eds., Les origines du Coran, le Coran des origines (Paris: Académie des Inscriptions et Belles-Lettres, 2015), 151-76. George built on Dutton's observations, focusing on manuscripts from the ninth-eleventh centuries. These observations are interpreted through al-Dāni’s treatise (al-Muhkam), see Alain George, "Coloured Dots and the Question of Regional Origins in Early Qur’ans (Part I),” JQS 17:1 (2015): 1-44 and (Part II), JQS 17:2 (2015): 75-102.

39 Mark Muehlhaeusler, “Additional Reading Marks in Kufic Manuscripts," JIS 27 (2016): 1-16 (14). 40 Kaplony, "What are those Few Dots for," 100.

41 These are, for example, the two readings expressed by a colour code of red vs. green dots in manuscript John Rylands Ar.688 [11], f.23r (fig. 5). Ibn Muğāhid reported the reading tahruğūna, i.e. the green vowel-dot level reading. I heartily thank the staff of the John Rylands Library for their promptness and kindness in helping me during my visiting fellowship at their Research Institute in summer 2015 when I had the chance to study MS Ar.688 [11] and other Qur'ānic fragments. 


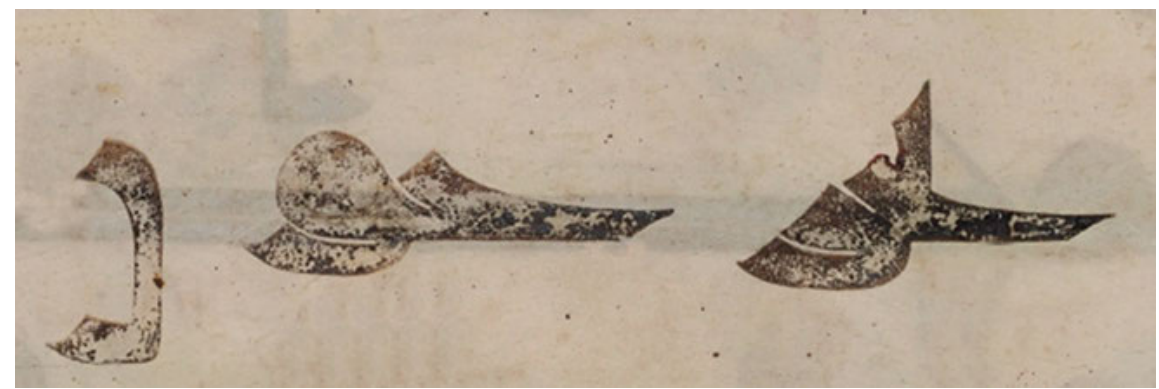

Fig. 1: Bare consonantal skeleton with homograph base letters: Arabic MS 11(688) f.23r, detail. John Rylands Library, The University of Manchester. Copyright of the University of Manchester. Layer extracted by Alba Fedeli.

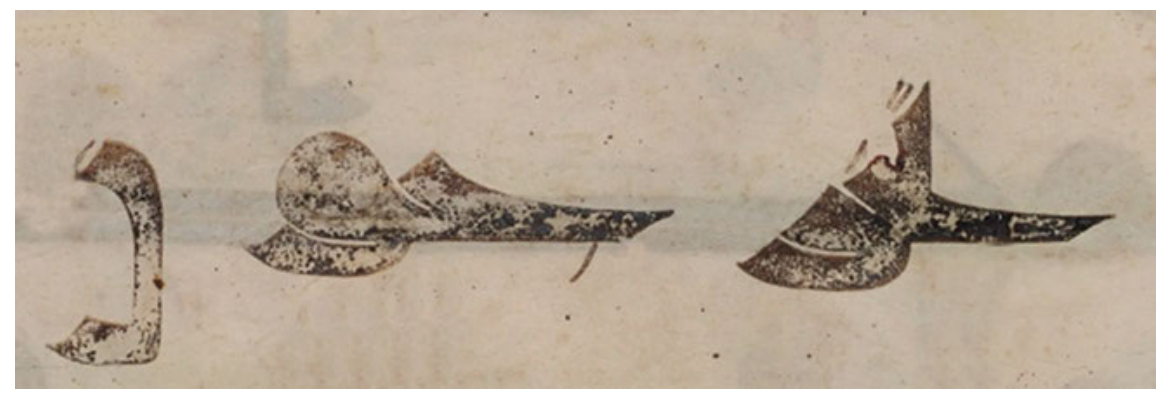

Fig. 2: Bare consonantal skeleton with explicit reading of possible homographs: Arabic MS 11(688) f.23r, detail. John Rylands Library, The University of Manchester. Copyright of the University of Manchester. Layer extracted by Alba Fedeli.

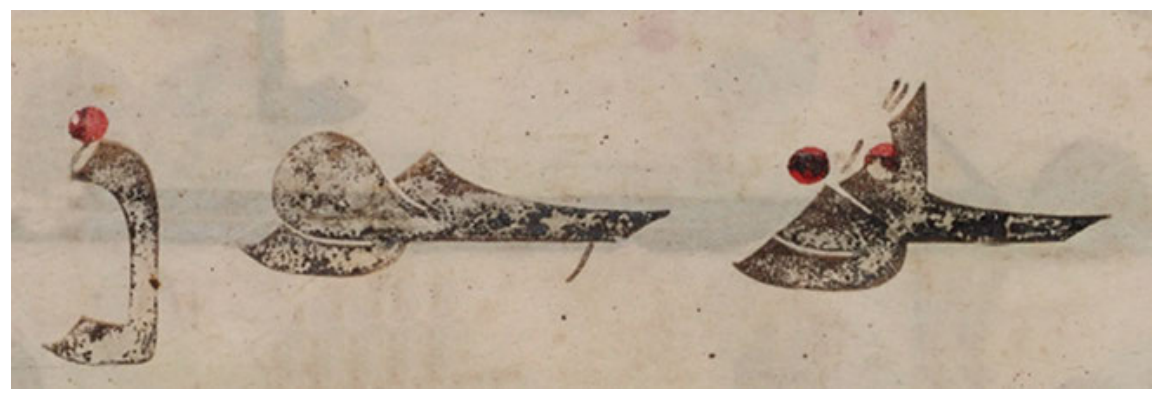

Fig. 3: Red vowel-dot level (tuhrağūna): Arabic MS 11(688) f.23r, detail. John Rylands Library, The University of Manchester. Copyright of the University of Manchester. Layers extracted by Alba Fedeli. 


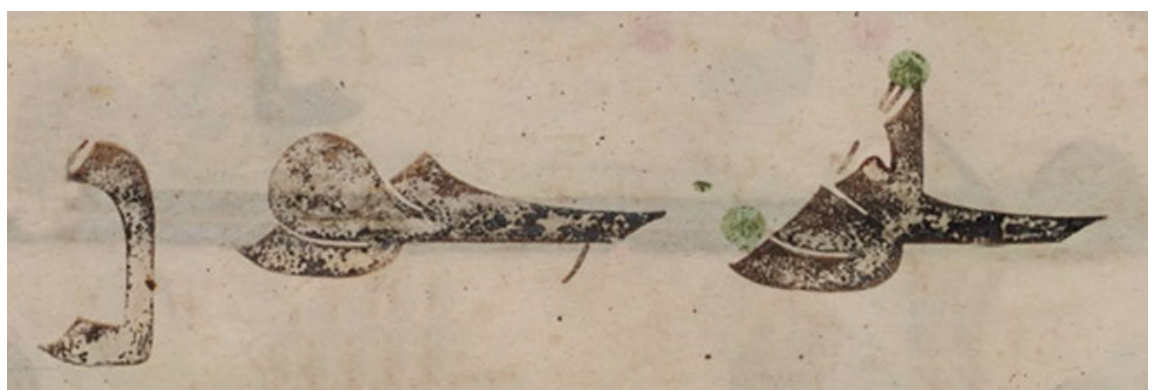

Fig. 4: Green vowel-dot level (tahruğūna): Arabic MS 11(688) f.23r, detail. John Rylands Library, The University of Manchester. Copyright of the University of Manchester. Layers extracted by Alba Fedeli.

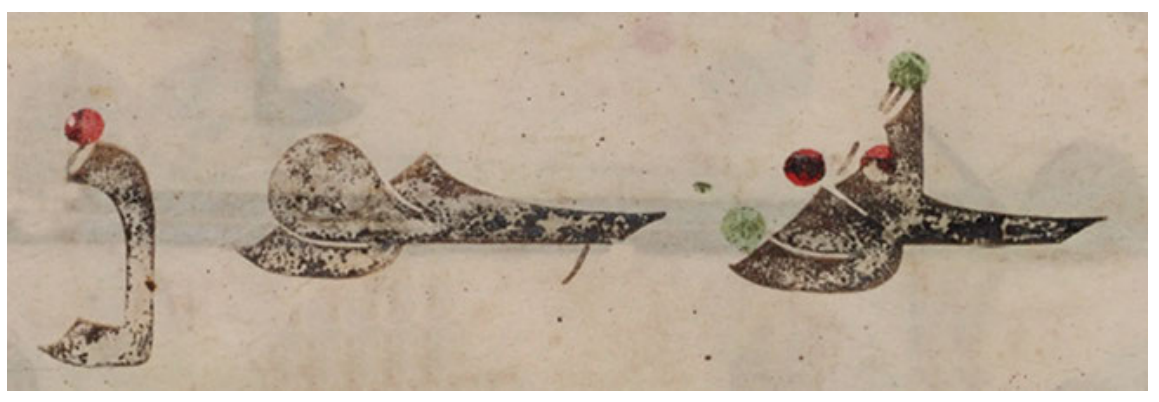

Fig. 5: Red and green vowel-dot levels: Arabic MS 11(688) f.23r, detail. John Rylands Library, The University of Manchester. Copyright of the University of Manchester.

similarities with the medieval musical notation system used in Europe. ${ }^{42}$ Guido d'Arezzo (b. circa 994), the inventor or at least the developer of the musical staff, proposed distinguishing musical lines by different colours, although the system was already in use in the Musica enchiriadis that inspired Guido's staff in the first place. Each line and its corresponding row should be assigned its own colour (i.e. red, green, yellow, and black). ${ }^{43}$ Moreover, medieval manuscripts could have most clefs written in the same brown ink as the notes, while further $\mathrm{C}$ clefs were drawn in red ink to change the clef. More interestingly, musical manuscripts show cases of green lines that could indicate, for example, a B-flat reference, as a musical act at once proofreading and prescribing how to read/sing a note as alternative

42 I thank Teunis van Lopik for calling my attention to the two references about colour system used in music.

43 John Haines, “The Origins of the Musical Staff,” The Musical Quarterly 91 (2008): 327-78 (331). 
to the first reading/singing indication. ${ }^{44}$ Thus, the use of red and green colours to express vowel dots can be seen as a mechanism for indicating the corresponding "clef of reading" of the consonantal skeleton of the Qur'ānic text as if colour indicates the "pitch" of written words.

The complexity of the writing code system of early Qur'ānic manuscripts can be seen as a means to express plurality rather than a repository of ambiguous signs that generate ambiguity and variant readings. The seeming imperfection of the system with its variant readings is possibly a necessary instrument rather than an inevitable consequence. In mentioning the problem of the variant readings as discussed in the work of Abū Bakr Ibn al-'Arabī, al-'Awāșim min alQawāṣim (i.e. "protections from catastrophes”), Nasser underlines that the collection and codification of the Qur'ān abrogated all the previous (pre-'Uthmānic) readings. Although copies of the Qur'ān (mașāhif) continued to be written and encoded without diacritics ( $\min$ gayr naqt wa-la dabt) in the same way as they were written during the time of Muhammad, the Prophet's companions transmitted how to read it and this non-disambiguated script of the Qur'ānic text was a flexible element (wa-hā $\underline{d} \bar{a}$ amr yasìr), since the absence of diacritics facilitated the diverse reading(s). This was important as there were already significant differences in reciting the Qur'ān. ${ }^{45}$

The homograph-based consonantal writing system is the basis of the script's fundamental ambiguity, and the flexible/arbitrary and partial use of the diacritics increases the ambiguity of the system. Although such ambiguity is generally considered to be the cause of the presence and diffusion of variants in reading the Qur'ānic text, the manuscript evidence also shows several cases of variant readings that are expressed by a different consonantal skeleton. ${ }^{46}$

44 Anna Zayaruznaya, "In Defense of Green Lines, or The Notation of B-flat in Early Ambrosian Antiphoners," in Ambrosiana at Harvard: New Sources of Milanese Chant, eds. Thomas Forrest Kelly and Matthew Mugmon (Cambridge, MA: Houghton Library of the Harvard College Library, 2010): 33-56, 50-51 and 55-56.

45 Shady Hekmat Nasser, The Transmission of the Variant Readings of the Qur'ān: The Problem of Tawātur and the Emergence of Shawādhdh (Leiden: Brill, 2013): 104-05. See Abū Bakr Ibn al'Arabī, al-'Awāṣsim min al-qawāṣim fī tahquĩ mawāqif al-ṣahāba (Beirut: Dar al-Kotob al-'Ilmiyah, 2010), 171.

46 See for example Alba Fedeli, "Early Evidences of Variant Readings in Qur’ānic Manuscripts,” in Die dunklen Anfänge. Neue Forschungen zur Entstehung und frühen Geschichte des Islam, eds. K.H. Ohlig and G.R. Puin (Berlin: Verlag Hans Schiler, 2005): 293-316; Asma Hilali, The Sanaa Palimpsest: The Transmission of the Qur'an in the First Centuries AH (Oxford: Oxford University Press in association with the Institute of Ismaili Studies, 2017); and François Déroche, Le Coran, une histoire plurielle (Paris: Éditions du Seuil, 2019). 


\subsection{Subdivision of the Text}

Variant readings are also impacted by the subdivision of the sequence of the Qur'ānic text. Scribes used several arrangements of space and layout to indicate the separation between sections of the text. Thus, scribes left one or two blank lines (i.e. bayād), which later could be filled in with simple decorations. They could also leave no bayā $d$ between two sūras. Consequently, they could accommodate the basmala (i.e. the incipit written before the beginning of each süra with the exception of sūrat at-Tawba) in different ways. In fact, there are examples of basmala written at the beginning of a new line as a continuum before the text, or as an independent line before the text starts on the following line or, lastly, placed in and adjusted to the available space left at the end of the previous surra.

Moreover, early manuscripts exhibit the insertion of devices to mark the end of each single verse (fāssila) in the form of clusters of strokes or dots (three or more strokes/dots arranged in a triangular or rectangular shape). Markers of ends of verses have been traced simultaneously or subsequently to the first writing of the text, and scribes could choose whether or not to leave space to accommodate these markers. At a later stage, likely in the same period of the introduction of the red vowel-dot system, special signs were added to indicate the end of a fifth and/ or tenth verse, that is, to annotate a five-verse group (a hams) or a ten-verse group (a ' $a s ̌ r$ ). Considering the fragmentary nature of early Qur'ānic manuscripts, which often contain incomplete sections of the text and thus an incomplete sequence of numbering of single verses, the annotation of a hams or a 'ašr constitutes a clear trace for verifying the counting system according to recognized or unknown numbering systems of the Qurānic text. ${ }^{47}$

Because of the presence of two parallel but distinct counting system annotations, first the notation of single verses and later the introduction of groups of five/ ten verses, there are situations where alternative numbering systems are simultaneously present. Manuscripts can have signs counting, for example, nine single verses notated by the first hand whereas a later hand counted those nine verses as a group of ten verses. In such a situation, it has to be noted that the later hand marked the group of ten verses without indicating the end of the extra tenth verse. Thus, there are no traces of corrections and additions to the first numbering of the

47 See Anton Spitaler, Die Verszählung des Koran nach islamischer Überlieferung, Sitzungsberichte der Bayerischen Akademie der Wissenschaften: Philosophisch-historische Abteilung 11 (München: Verlag der Bayerischen Akademie der Wissenschaften, 1935). 
nine verses, but the 'ašr could be considered as an instruction for interpreting the text sequence, a sort of concordance between the two numbering systems. ${ }^{48}$

\subsection{Interpretation of the Script: Ambiguity of Incomplete or Obscure Disambiguating System}

The Arabic writing system in early Qur'ānic manuscripts accommodates simultaneously competing interpretations that imply that the ambiguity of their script is a constitutive ambiguity rather than a contingent one because of the phenomenon of the multiple layers of readings. ${ }^{49}$ Similarly, following Ibn al-'Arabì's interpretation of the non-disambiguated script of the Qur'ānic text as a flexible tool that facilitated the existing different readings, the underspecified consonantal skeleton is a tool for a communication strategy of tolerance for ambiguity rather than an accidental phenomenon.

Moreover, the sophisticated form of the ambiguous script in Qur'ānic manuscripts generates two challenging situations. In fact, in some cases, disambiguating vowel diacritics (naqt) and $i$ ' $\breve{g} \bar{a} m$ diacritics are partially added to the consonantal skeleton in a seemingly accidental manner or in an obscure way, thus generating further ambiguity. In other words, the resulting ambiguity suspends the disambiguation system..$^{50}$

As regards the first case, the partial addition of disambiguating vowel dots and consonantal strokes, Kaplony - as above-mentioned - observed that $i$ ' $\breve{g} \bar{m} m$ diacritics specified grammatical categories in specific environments, primarily marked affixes and particles. Nevertheless, a systematic analysis of the environments in which these diacritics are placed is still a desideratum. As regards vowel dots placed in certain positions, previous scholarship has interpreted them through the lens of the eleventh century Islamic literature on the subject, considering the vowel dots as segmental signs which are physically attached to a single consonantal element. Thus, from this perspective, both classical works and modern studies

48 This is for example the situation in MS National Library of Russia Marcel 17, MS Mingana Islamic Arabic 1572b and MS Museum of Islamic Art in Doha, Qatar, MIA67. Thus, for example, in Q.3, the first hand counts nine verses between Q.3:22 and Q.3:30 and eleven verses between Q.3:31 and Q.3:41, whereas the later red layer counts ten verses in both cases. The black layer counts ten verses between Q.3:22-31 and Q.3:32-41, in agreement with the first hand (MS NLR Marcel 17, f.3). See Fedeli, Early Qur'ānic Manuscripts, their Text, 237-38, 250-55.

49 On the classification of elementary, hermeneutic, and constitutive ambiguity, see Frauke Berndt and Klaus Sachs-Hombach, "Dimensions of Constitutive Ambiguity," in Ambiguity: Language and Communication, ed. Susanne Winkler (Berlin: De Gruyter, 2015): 271-82.

50 Berndt and Sachs-Hombach, “Dimensions of Constitutive Ambiguity,” 272. 
note that vowel dots could indicate grammatical endings or distinguish homographs. However, this interpretation does not seem to be able to explain all dots in manuscripts as there are vowel diacritics added in unambiguous situations. ${ }^{51}$

An example of a more challenging situation is the hiğ $\bar{a} z \bar{\imath}$ manuscript scattered between Birmingham, Doha, and St. Petersburg (Mingana Isl. Ar. 1572b, NLR Marcel 17, and MIA MS67). This manuscript features several cases of red vowel dots that cannot be explained through the available literature on Arabic vocalization systems. The manuscript is the result of several writing stages, having three distinct layers of ink. The first layer - written with brown ink - features the consonantal skeleton, a few diacritical strokes, and markers at the ends of verses. The second layer, in black ink, provides some amendments. The third layer, in red ink, does four things. It provides some amendments to the consonantal skeleton, it retraces the text where the ink has faded, it adds vowel dots, and it marks groups of verses. This shows that the vocalization system was added to the consonantal skeleton at a later stage. The hiğ $\bar{a} z \bar{\imath}$ style of the script can be traced to the seventh or eighth century and it is likely that the red vowel dots were added at least a few decades later. Several dots are placed in positions that are obscure and even (grammatically) impossible. For example, the final tanwin ending of nouns (-un) occurs after one verbal form with the feminine perfect tense ending (-at). Analysing a fragment of the manuscript (the Birmingham leaves), Dutton identified traces of a Syrian reading tradition, including variations related to the consonantal skeleton, diacritical strokes, and red dot vowels. However, in his interpretation of the variations, Dutton observed that a few red dots are placed in a "non-accurate" way: "Red dots, however, directly above the mims of munkhaniqa and mutaraddiya suggest that these vowels may not always have been positioned in what one might consider an accurate way by later standards!" 52

Here, the theory of markup system as diacritics in digital editing can shed light in understanding first, some obscure examples of diacritics whose main function is supposedly to disambiguate the script and second, the sophisticated nature of the multiple readings that simultaneously exist and which are accommodated by the ambiguous script.

51 For example, in MS John Rylands Ar.688 [11], probably dating from the ninth century, a single vowel dot has been added to the entire consonantal skeleton of lā yaškurūna (i.e. "[but most of the people] are not grateful," Q.12:38 in f. 2r), i.e. one dot above the final nūn to mark /a/. The consonantal skeleton is not specified by means of consonantal diacritics - thus leaving Y S S [N] as ambiguous homographs - and the only added vowel diacritic has been added to the final ending - ūna, which seems an unambiguous situation.

52 Yasin Dutton, “Two 'Hijāzī' Fragments of the Qur'an and Their Variants, or: When Did the Shawādhdh Become Shādhdh?,” JIM 8 (2017): 1-56 (22). 


\section{The Digital Encoding Perspective}

\subsection{Textual Space and Active Readers}

The text of early manuscripts is multilayered both because of their historical physical strata and their constitutive ambiguity that accommodates and facilitates simultaneous competing readings. This kind of "open text" in early manuscripts overlaps with the idea of the digital text and its hyperdimensions, in particular hypertextuality or multilayered strata. In fact, building upon Barthes, Mordenti reflected on how the Gutenberg textual product constrains the role of the reader, whereas the readers should be entitled to a greater role in understanding the text as they make their way through the meaningful segments of the text. ${ }^{53}$ Thus, for example, the active role of the reader in the digital text has a correspondence to the handwritten manuscript culture: we have traces of this process of passing through the text in the examples of alternative readings expressed (tagged) in early Qur'ānic manuscripts. The "hyper” textual space is dynamic and its reader, or user, has an active role in a digital textspace, whereas the book is perceived and used as a static object. ${ }^{54}$ The hypertextual digital space and the fluid and multilayered manuscript text overlap at a few points, since both their readers are active in choosing one level of the possible readings of the text.

More specifically, with regard to editing manuscript texts in a digital horizon, technical possibilities allow texts from all of the manuscript evidence to be transcribed, documented and stored. In a traditional (critical) edition, this abundance of details about the history of the production of the documents is limited to the apparatus criticus as regards its textual variants, while its linguistic diversity tends to be regularized. The consequence of this different approach in editing due to different technological possibilities (i.e. hyperdimensions and digital space vs. linear text and printing technology) is crucial. The editions produced in digital encoding are digital documentary editions. ${ }^{55}$ They are not critical editions in the sense of a reconstruction of the possible original archetype, as they aim to edit and tag the richness of the manuscript text rather than to recover the original text (on similar issues in Christian texts, see the essay from Allen in the present volume).

53 Mordenti, "Parádosis."

54 Jerome McGann, "Coda: Why Digital Textual Scholarship Matters; Or, Philology in a New Key," in The Cambridge Companion to Textual Scholarship, eds. Neil Fraistat and Julia Flanders (Cambridge: Cambridge University Press, 2013): 274-88 (279). See also Mordenti above mentioned as pertains to the active role of the reader in the post-Gutenberg era.

55 Elena Pierazzo, “Digital Documentary Editions and the Others," Scholarly Editing: The Annual of the Association for Documentary Editing 35 (2014): 1-23. 


\subsection{Notational Markup and Inference Ticket}

In a digital horizon of editing of early Qur'ānic manuscripts, two aspects of markup are particularly relevant to decoding the system used in these manuscripts: interpretative and diacritical functions.

The fundamental aspect of digitally editing manuscripts lies in tagging the manuscript text and its features. Like scribes, digital editors transcribe and describe the text - and object - adding metalinguistic notes. They can annotate the text following accepted standards of markup languages, thus encoding the text. Editors can use, for example, the standard language of the Text Encoding Initiative (TEI) whose markup data model is based on an embedded XML markup. Markup is the use of embedded codes to describe the structure of a document or to insert instructions related to its layout that can be used by a layout processor. ${ }^{56}$

Thus, in editing Qur'ānic manuscript texts, digital humanists can use: (1) inline additions of categories to word segments using opening and closing elements that circumscribe and describe a section of the manuscript text; (2) markers for encoding the structural unit of the text (e.g. beginning of süra or beginning of verse); (3) entities to mark paratextual elements like the device to indicate the end of a verse; and (4) editorial and local notes to comment on and annotate the text or other features of the object, such as the comparison between a particular reading of the manuscript and a reading recognized in the qir $\bar{a} \cdot \bar{a} t$ literature. ${ }^{57}$

In editing manuscripts, markup languages make explicit certain features of a text based on codex/leaves technology, and exhibit these features "by bringing them forth visibly into the expression of the text" - markup languages are thus "essentially notational." 58 As markup is able to make evident the various implicit features of the text, it is able to handle the full range of the editor's choices. The markup encoding makes explicit the code of the artefact and its text according to the editor's interpretation without relying on the reader's above-mentioned ability to handle the ambiguity. Markup is an instrument "to make (license) certain inferences about passages in the marked-up material"; it thus remains

56 Darrell R. Raymond, Frank Wm. Tompa, and Derick Wood, “Markup Reconsidered,” (paper presented at the First International Workshop on Principles of Document Processing, Washington, D.C., October 21-23, 1992): 1-20 (1).

57 This is, for example, the work I did in editing the Cambridge Qur'ānic palimpsest now available in the Cambridge Digital Library (https://cudl.lib.cam.ac.uk/collections/minganalewis/1). See Alba Fedeli, Edition of the Qur'ānic Leaves of Palimpsest Manuscript CUL Or. 1287 (Cambridge: Cambridge Digital Library, 2016).

58 Dino Buzzetti and Jerome McGann, “Critical Editing in a Digital Horizon," in Electronic Textual Editing, eds. Lou Burnard, Katherine O'Brien O'Keeffe and John Unsworth (New York: The Modern Language Association of America, 2006): 53-73 (61). 
interpretative as it reflects the understanding of the text by the transcriber. ${ }^{59}$ The idea of markup as an interpretative act that generates inferences corresponds to seeing it as an "inference ticket" as underlined by Buzzetti. ${ }^{60}$ Both markup and diacritics have a double value of operator and operand. They are, at the same time, operational - as they provide metalinguistic instructions and inference ticket - and referential - as they are signs of the object language.

\subsection{Suprasegmental Markup and Diacritics}

In digital editing theory, markup can be viewed as a diacritical sign. Markup carries out a proper diacritical function with respect to the text. ${ }^{61}$ In fact, diacritics can be part of the text or an external comment on it. ${ }^{62}$ Raymond, Tompa, and Wood have compared markup to diacritics in consonantal scripts. They noticed that the earliest types of markup were intended "to facilitate the reading process," giving as examples the diacritics employed to signify vocalic distinction and the decorations that identify breaks and subdivision in a text sequence. ${ }^{63}$

In relation to the use and function of diacritics in early Qur'ānic manuscripts, it is important to underline the crucial difference between diacritics that, being part of the text, produce a "textual variant" and diacritics that, being external description related to the text, produce a "variant interpretation." 64 Diacritics and markup can be part of the text - thus object language - or external description to the text - thus metalanguage. What later layers added to an early Qur'ānic manuscript text, whether object text or metalanguage, will be discussed below.

59 C.Michael Sperberg-McQueen, Claus Huitfeldt and Allen Renear, "Meaning and Interpretation of Markup,” Markup Languages: Theory \& Practice 2.3 (2000): 215-34.

60 Buzzetti uses Gilbert Ryle's locution referring to the licence that the possessor of an inference ticket has to provide explanations of given facts. See Dino Buzzetti, "Codifica del testo e intelligenza artificiale,” Schede Umanistiche 17 (2003): 171-97 (188-90) and Buzzetti, "Biblioteche digitali e oggetti digitali complessi," 71, and mentioned also by Buzzetti and McGann, "Critical Editing in a Digital Horizon," 66-67.

61 Dino Buzzetti, "Diacritical Ambiguity and Markup," in Augmenting Comprehension: Digital Tools and the History of Ideas. Proceedings of a Conference at Bologna, 22-23 September 2002, eds. Dino Buzzetti, Giuliano Pancaldi and Harold Short (London: Office for Humanities Communication Publication, 17, 2004): 175-88 (178).

62 Buzzetti and McGann, "Critical Editing in a Digital Horizon," 65.

63 Raymond, Tompa, and Wood, "Markup Reconsidered," 2.

64 In digital editing theory, the distinction is underlined in Buzzetti and McGann, "Critical Editing in a Digital Horizon," 65. 
Moreover, inasmuch as markup has a diacritical function separable from the text, it can be metalinguistic description of the structure of the text. Consequently, as stated by Buzzetti, "out-of-line markup [...] is a form of metalinguistic markup independent of the position of the tags in the sequence of codified characters. This enables us to assign to the expression of the text also nonlinear and overlapping hierarchical structures. Distinct interpretative variants can thus be assigned to the structure of the text." ${ }^{65}$ Here Buzzetti recalls Raymond, Tompa, and Wood's distinction between strongly and weakly embedded tags. Their difference lies in the function of the tags' position. In strongly embedded markup, the position of the markup is information-bearing, while a weakly embedded markup can be placed at any point in the text as its position is not information-bearing. ${ }^{66}$ In other words, markup can be segmental or suprasegmental, thus referring to a precise segment of the text or to more segments. If the position is not information-bearing, editors/ readers can also assign nonlinear and overlapping structures.

\section{The Textual Environment of the Qur'ānic Manuscript Interpreted in Light of the Digital Encoding Perspective: Diacritical and Notational Markup}

\subsection{Suprasegmental Diacritics: The Digital Horizon and the Syriac Parallel}

Moving to a closer look at the Qur'ānic manuscript textual environment as interpreted in light of the digital encoding perspective, the latter offers interesting insights about diacritical and notational markup, in particular with regard to a few obscure examples of vowel dots added to early Qur'ānic manuscripts. The above-mentioned manuscript scattered in Birmingham, St. Petersburg, and Doha has some puzzling positions in which red vowel-dot diacritics have been placed. Dutton explains these vowel dots in impossible positions as the result of inaccuracy by the person who placed them "in what one might consider an accurate way by later standards!”

65 Buzzetti, “Diacritical Ambiguity and Markup,” 185.

66 Raymond, Tompa, and Wood, "Markup Reconsidered," 3-4. 
However, if we look at a few of these inexplicable vowel dots from the perspective of markup theory in digital encoding, their positions may or may not be information-bearing, and thus they can be placed at any point in the text segment. This perspective turns out to be effective, when considering diacritics as suprasegmental signs (operators with operational value) and not as mere segmental signs (operands with referential value), thus coinciding with the perspective of the Syriac dots noted above. In fact, Syriac dots can have both the function of segmental signs bound to a single base graph and suprasegmental signs, so that some dots mark phonemes while others tag entire words or expressions like metalinguistic markup, as observed by Kiraz. ${ }^{67}$ Considering the similarities of the Arabic diacritics with the functions of the Syriac dots ${ }^{68}$ also solves the chronological aspect of the problem. As stressed by Dutton, some Qur'ānic vowel dots do not correspond to later standards dating from the tenth or eleventh centuries. Thus it seems to be more effective to compare the Qur'ānic dots that were introduced in the eighth-ninth century with contemporary examples such as the Syriac dots indicating syāmē or mhaydānā, or those marking a feminine ending. All three of these signs appeared in Syriac manuscripts in the eighth century.

An example of the nonsegmental and nonphonemic value of vowel dots is in Q.6:138: wa-an'( $\bar{a})$ mun hurrimat zuhūru-ha, i.e. "(These are) cattle whose backs are forbidden.” In MS Mingana Islamic Arabic 1572b, f.8v (the Birmingham portion of the larger manuscript), the two dots at the end of the verb hurrimat cannot be read as a final nominal tanwin ending (-un). As nonsegmental and nonphonemic signs, they could indicate the assimilation between the final $t a^{\prime}$ and the initial $z a^{\prime}$ of the following word, thus corresponding to the mhaydāna ("uniting") dotting of Syriac ${ }^{69}$ that also coincides with the representation of examples of alif al-wașl (the phonetic liaison between two words) in Qur'ānic manuscripts. ${ }^{70}$

This alternative approach in explaining obscure vowel dots (naqt diacritics) in early Qur'ānic manuscripts has to be extended to the perspective on the entire system of naqt- and $i$ ' $\breve{g} \bar{a} m$ diacritics. If the diacritical system of Qur'ānic manuscripts originated from a nonphonemic suprasegmental function of markup as

67 See George Anton Kiraz, The Syriac Dot. A Short History (Piscataway, NJ: Gorgias Press, 2015), 99-102. An example of a suprasegmental dot is the syāme, i.e. the pair of dots referred to an entire word and indicating its plural form that is not bound to a single base graph but is suprasegmental and its position is not information-bearing.

68 See, for example, Kiraz on the morphological tagging of dots (Kiraz, The Syriac Dot, 76, 79).

69 Kiraz, The Syriac Dot, 118.

70 Recently, I suggested a few readings of vowel-dots in MS NLR Marcel 17, Mingana Islamic Arabic 1572b and MIA67 in light of the metalinguistic markup approach of digital encoding and similarities with the Syriac dotting system. However, a more systematic analysis of the dotting system in Qur'ānic manuscripts in a comparative perspective with Syriac is needed. 
operator, this would enable a nonlinear and overlapping structure to be assigned to the consonantal skeleton of words. The phenomenon of alternative and coexisting readings marked by more than one layer of diacritics is an argument supporting the hypothesis of the position of diacritics as non-information-bearing and their similarity to a weakly embedded markup in digitally encoding, mentioned above.

\subsection{The Nonlinear Structure}

Coexisting readings of a single word or a sequence of words as well as parallel counting systems can be seen as overlapping and nonlinear structures of the Arabic script. Thus, as in the example above, the sequence / T H R Ğ W N/ can be read following one "clef" as tuhrağūna and/or following the other "clef" as tahruğūna (fig. 5). Its consonantal skeleton can be seen as notes on a musical staff in which the red and green colours indicate the pitch of those notes, similar to the use of colours in medieval musical manuscripts. Interestingly, Monella proposed a "musical score" model for digital scholarly editions with three parallel transcriptions of the text (graphical layer, alphabetic layer, and linguistic layer) which are mapped on to one another. ${ }^{71}$ This model would help solve the inconsistency of manuscripts at the graphical and alphabetic layers without normalizing the possible significant different orthographies and different ways of diacritization, while also perfectly fitting the digital edition of the coexistent multiple layers of readings as they are expressed - for example - by different colours.

\subsection{The Notational Markup and the Inference Ticket}

The second aspect of markup languages in digital editing that shows similarities with the manuscript situation is the notational function of markup. In digital editing, the difference between diacritical markup as part of the text (object text) and as external comment on it (metalanguage) is evident. Such distinct perspective can shed light on the markup of embedded additions and amendments to early Qur'ānic manuscripts. The perspective on later additions as being metalinguistic rather than only object language that changes the text is connected with the suprasegmental value of diacritics.

71 Monella, “Many Witnesses, Many Layers,” section 3. 
Markup is the use of embedded codes to make explicit certain features of a manuscript text, thus expressing its interpretative nature given by its being an "inference ticket" as mentioned above with reference to Buzzetti's analysis. If we consider, for example, the situation in which a later, different annotation of the numbering system used in counting the Qur'ānic verses is added to the first annotation, the "inference ticket" value of the later annotation is evident. The two markers of the numbering system run parallel and the second layer does not have the function of correcting the first layer of markers. The manuscript is the space of the encounter between two codes. If the person who added a different layer at a later stage had meant to correct the numbering system (thus adding a markup with the value of a text object), they would have added the end of verse marker at the tenth extra verse. ${ }^{72}$ It is likely that their intention was to annotate instructions for the interpretation of the numbering system, thus providing a sort of concordance in order to steer readers who had the other numbering system in mind. The second layer of ten-verse groups in the Birmingham, St. Petersburg, and Doha manuscript represents a sort of reading instruction rather than a correction and expresses the life of the manuscript and its changes over time.

Thus, notational function of markup in digitally encoding provides new insight into interpreting some aspects of the manuscript culture.

\section{Standoff Markup for a Phylogenetic Analysis: Further Directions in Editing Early Qur'ānic Manuscripts}

\subsection{Functionality of Digital Editing}

Undeniably, the use of digital scholarly editing influences the approach to the text, and the concept of an original text is replaced by the idea that each manuscript has its own right to be the text. Collecting and displaying as many Qur'ānic manuscripts and their editions as possible is crucially important in Qur'ānic studies from an epistemological point of view because of the different point of view on the idea of an original text and the new focus on the history of the transmission of the text. Nevertheless, the mere visualization of digital editions of

72 On the details about the numbering systems of verses in this manuscript, see Fedeli, Early Qur'ānic Manuscripts, 237-38, 250-55. 
Qur'ānic manuscripts does not fully relay all that is required in the digital representation of information.

In fact, the final aim of scholars' work in editing and transmitting manuscript texts is not the mere reproduction of the original document, for example in a diplomatic edition, but the provision of a format that is readable and interpretable. Digital representation has to meet two fundamental requirements: thoroughness and functionality. The digital data assembled in editing manuscript texts have to be not only complete and accurate but also functional for computational elaboration. ${ }^{73}$

An example of the functionality of Qur'ānic manuscript editions in terms of the computational analysis of manuscript data beyond their mere online visualization is the phylogenetic analysis of Qur'ānic manuscripts. Phylogenetic software - developed in biology to group species based on DNA sequences - can be used to understand the possible relationships between several manuscripts in order to reconstruct their possible context and production process. Thus, textual studies merged with information technology and biology can contribute to the knowledge of the transmission of the Qur'ānic text by collecting and comparing data from manuscript evidence. In a testing phase of a phylogenetic analysis project on early Qur'ānic manuscripts, ${ }^{74}$ I had to face three main challenges, thus envisaging possible solutions and further directions of research in Qur'ānic manuscript studies: (1) removing embedded markup, (2) presenting multi-layered editions like the musical score model, and (3) highlighting the materiality of the manuscript.

In my experience in the digital scholarly editing of Qur'ānic manuscripts, I faced the challenge of removing embedded markup in order to compare editions of different manuscripts in their different layers. Recent scholarship has formulated a hypothesis on the limitations of embedded markup and the advantages of standoff markup in order to guarantee interoperability and standardization. ${ }^{75}$

73 Buzzetti very sharply distinguished between "esaustività e funzionalità della conservazione dell'informazione." See Buzzetti, "Biblioteche digitali e oggetti digitali complessi," 41-43.

74 Alba Fedeli and Andrew Edmondson, "Early Qur’ānic Manuscripts and their Networks: a Phylogenetic Analysis Project,” pre-circulating paper for the Conference "Qur'ānic Manuscript Studies: State of the Field,” Budapest May 2017 after the research project Early Qur'ānic Manuscripts and their Relationship as Studied Through Phylogenetic Software at the Central European University, Budapest.

75 See for example Desmond Schmidt, "The Role of Markup in the Digital Humanities," Historical Social Research 37/3 (2012): 125-46, and Desmond Allan Schmidt, "Using Standoff Properties for Marking-up Historical Documents in the Humanities," Information Technology 58/2 (2016): 63-69. 


\subsection{Edition of Separate Layers: Standoff Markup and Merged Versions}

In editing early Qur'ānic manuscripts, I inserted markup codes to express the stratigraphic nature of these objects and observe the presence of comments or amendments (ante litteram markup) made by later users. In my phylogenetic analysis project, it was essential to distinguish the different strata of each manuscript in order to compare single images - in Segre's view ${ }^{76}$ - of manuscript texts. A standoff markup system and the consequent technical possibility of producing a multi-version document (MVD) model would allow editing of the separate layers of each manuscript as part of a single document, thus representing a text as a set of merged versions in a single digital entity. ${ }^{77}$

Similarly, distinct manuscript strata refer not only to different historical moments in the production and use of the manuscripts, but also to different graphic systems used in different times and places. The main challenge to solve in the already-concluded phylogenetic project has been the treatment of words that approach the use of diacritical signs differently. The constitutive ambiguity of Arabic script based on the possible use of diacritics generates a difficult situation, as phylogenetic software has to process words that potentially convey the same information but are graphically different. The homograph base letter that can be disambiguated by means of a diacritic is processed differently if it is with or without diacritics, although for the "tolerant and discriminating reader" the two different Unicode points are two different pieces of information to be treated and compared. As Unicode is not sufficient on its own in editing early Qur'ānic manuscripts, their richness, and their variety of graphic systems, a solution based on the distinction of the graphical layer, alphabetic layer, and linguistic layer as suggested by Monella seems to be more convincing. This would allow Unicode to be used efficiently and these early manuscripts to be collated and their data searched. The musical score model developed by Monella seems to be a possible new direction for editing manuscripts.

76 "Image of the text" refers to Segre's interpretation that this image is a linguistic structure that performs a system. See Cesare Segre, Semiotica filologica. Testo e modelli culturali (Torino: Giulio Einaudi editore, 1979), 64-65.

77 See Desmond Schmidt and Robert Colomb, “A Data Structure for Representing Multi-Version Texts Online,” International Journal of Human-Computer Studies 67 (2009): 497-514. 


\subsection{Annotations About Materiality}

Lastly, a desideratum that I considered and partially included in my phylogenetic analysis project is the creation of data referring to the materiality of the manuscripts. In my spreadsheet, I introduced not only the transcription of the Qur'ānic text, but also information about the paratextual elements, the layout of the page, and the writing system: this included format (vertical or horizontal); ruling (yes or no); bayād (yes or no); size of the leaves; number of lines; and the layout of the basmala (independent or consecutive before the beginning of the verse). With regard to the writing system, a typology of characters used for every single letter was introduced. The introduction of these paratextual elements, physical arrangement of the text, and script characteristics was prompted by previous studies which have applied phylogenetic analysis to physical artefacts that can be analysed insofar as they are encoded in an appropriate way. ${ }^{78}$

This consideration of the encoding of elements related to the object's materiality brings into discussion the importance of including annotations about materiality in scholarly editing in order to produce a "social text editing". In his 1999 study Bibliography and the Sociology of Texts, McKenzie stressed the importance of the medium in effecting its message and thus supporting the need to include the relationship between form, function, and symbolic meaning in bibliography. Reading and rereading, editing and reediting a manuscript text should take into consideration the history of the readings of that object without borders "between bibliography and textual criticism on the one hand and literary criticism and literary history on the other."79

Thus, we return to our starting point that texts cannot exist as divested of their material form and technology, which influence the idea of the text itself. Digital scholarly editions and their computational analyses (for example, using phylogenetic software) likewise cannot disregard the material aspects of manuscripts, with all their cultural and social value.

78 Christopher J. Howe and Heather F. Windram, "Phylomemetics - Evolutionary Analysis Beyond the Gene,” PLoS Biology 9.5 (2011), e1001069. doi:10.1371/journal.pbio.1001069.

79 Donald Francis McKenzie, Bibliography and the Sociology of Texts (Cambridge: Cambridge University Press, 2009 [1999]), 10, 23. 


\section{Bibliography}

Agati, Maria Luisa. The Manuscript Book: A Compendium of Codicology. Trans. Colin W. Swift. Roma: L'Erma di Bretschneider, 2017 [2009].

Alsmadi, Izzat M. "Techniques to Preserve the Integrity of the Electronic Versions of the Nobel Quran.” In Proceedings of 2013 Taibah University International Conference on Advances in Information Technology for the Holy Quran and Its Sciences, NOORIC 2013 edited by Juan E. Guerrero, 52-56. Piscataway, NJ: The Institute of Electrical and Electronics Engineers, Inc., Conference Publishing Service, IEEE Service Center, 2015.

Avalle, D’Arco Silvio. "I canzonieri: definizione di genere e problemi di edizione." In La critica del testo. Atti del Convegno di Lecce, 22-26 ott. 1984, 363-382. Roma: Salerno Editrice, 1985.

Berndt, Frauke and Klaus Sachs-Hombach. "Dimensions of Constitutive Ambiguity." In Ambiguity: Language and Communication, edited by Susanne Winkler, 271-282. Berlin: De Gruyter, 2015.

Bodin, Jean. Colloque entre sept scavans qui sont de differens sentimens: des secrets cachez des choses relevées, traduction anonyme du Colloquium heptaplomeres de Jean Bodin (manuscrit français 1923 de la Bibliothèque Nationale de Paris), edited by François Berriot, Katharine Davies, Jean Larmat, Jacques Roger. Genève: Librairie Droz, 1984.

Burton, John. "mușhaf.” In Encyclopaedia of Islam, Second Edition, edited by C.E. Bosworth, E. van Donzel and W.P. Heinrichs and Ch. Pellat, vol. 7, 668-69. Leiden: Brill, 1993.

Buzzetti, Dino and Jerome McGann. "Critical Editing in a Digital Horizon.” In Electronic Textual Editing, edited by Lou Burnard, Katherine O’Brien O’Keeffe and John Unsworth, 53-73. New York: The Modern Language Association of America, 2006.

Buzzetti, Dino. "Biblioteche digitali e oggetti digitali complessi: Esaustività e funzionalità nella conservazione." In Archivi informatici per il patrimonio culturale, Convegno internazionale organizzato dall'Accademia Nazionale dei Lincei in collaborazione con ERPANET e la Fondazione Franceschini, 41-75. Roma: Accademia Nazionale dei Lincei, Bardi Editore, 2006.

Buzzetti, Dino. "Diacritical Ambiguity and Markup." In Augmenting Comprehension. Digital Tools and the History of Ideas. Proceedings of a Conference at Bologna, 22-23 September 2002, edited by Dino Buzzetti, Giuliano Pancaldi and Harold Short, 175-188. London: Office for Humanities Communication Publication, 17, 2004.

Buzzetti, Dino. “Codifica del testo e intelligenza artificiale.” Schede Umanistiche 17.1 (2003): 171-97.

Cellard, Eléonore. "La vocalisation des manuscrits coraniques dans les premiers siècles de l'islam." In Les origines du Coran, le Coran des origines, edited by François Déroche, Christian J. Robin and Michel Zink, 151-76. Paris: Académie des Inscriptions et BellesLettres, 2015.

D’Ottone, Arianna. "The Blue Koran: A Contribution to the Debate on Its Possible Origin and Date." JIM 8 (2017): 127-43.

Déroche, François, ed. Islamic Codicology: An Introduction to the Study of Manuscripts in Arabic Script. Trans. Deke Dusinberre and David Radzinowicz. London: Al-Furqān Islamic Heritage Foundation, 2005-2006.

Déroche, François. “Codicology.” In Encyclopaedia of Islam Three, edited by Kate Fleet, Gudrun Krämer, Denis Matringe, John Nawas, Everett Rowson, Vol. 1, 26-39. Leiden: Brill, 2017. 
Déroche, François. La Transmission Écrite du Coran Dans les Débuts de L'Islam: Le Codex Parisino-Petropolitanus. Leiden and Boston: Brill, 2009.

Déroche, François. Le Coran, une histoire plurielle. Paris: Éditions du Seuil, 2019.

Dutton, Yasin. "Red Dots, Green Dots, Yellow Dots and Blue: Some Reflections on the Vocalisation of Early Qur'anic Manuscripts - Part I.” JQS 1 (1999): 115-40.

Dutton, Yasin. "Red Dots, Green Dots, Yellow Dots and Blue: Some Reflections on the Vocalisation of Early Qur'anic Manuscripts - Part II." JQS 2 (2000): 1-24.

Dutton, Yasin. “Two 'Ỵijāzỉ’ Fragments of the Qur'an and Their Variants, or: When Did the Shawādhdh Become Shādhdh?" JIM 8 (2017): 1-56.

Fedeli, Alba. “Early Evidences of Variant Readings in Qur’ānic Manuscripts.” In Die dunklen Anfänge. Neue Forschungen zur Entstehung und frühen Geschichte des Islam, edited by Karl-Heinz Ohlig and Gerd-R. Puin, 293-316. Berlin: Verlag Hans Schiler, 2005.

Fedeli, Alba. Early Qur'ānic Manuscripts, their Text, and the Alphonse Mingana Papers Held in the Department of Special Collections of the University of Birmingham. PhD thesis. Birmingham: University of Birmingham, 2015.

Fedeli, Alba. Edition of the Qur'änic Leaves of Palimpsest Manuscript CUL Or. 1287. Cambridge: Cambridge Digital Library, 2016. Online: https://cudl.lib.cam.ac.uk/collections/ minganalewis/1.

Gacek, Adam. Arabic Manuscripts: A Vademecum for Readers. Leiden: Brill, 2009.

George, Alain. “Coloured Dots and the Question of Regional Origins in Early Qur'ans (Part I).” JQS 17 (2015): 1-44.

George, Alain. “Coloured Dots and the Question of Regional Origins in Early Qur'ans (Part II).” JQS 17 (2015): 75-102.

George, Alain. The Rise of Islamic Calligraphy. London and Beirut: Saqi Books, 2010.

Ghabban, 'Ali Ibn Ibrahim and Robert Hoyland. "The Inscription of Zuhayr, the Oldest Islamic Inscription (24 AH/AD 644-645), the Rise of the Arabic Script and the Nature of the Early Islamic State." Arabian Archaeology and Epigraphy 19 (2008): 210-37.

Ghul, Omar Al-. "An Early Arabic Inscription from Petra Carrying Diacritic Marks.” Syria 81 (2004): 105-18.

Goitein, Shlomo Dov. A Mediterranean Society: The Jewish Communities of the Arab World as Portrayed in the Documents of the Cairo Genizah. Vol. 1, Economic Foundations. Berkeley: University of California Press, 1967.

Goitein, Shlomo Dov. A Mediterranean Society: The Jewish Communities of the Arab World as Portrayed in the Documents of the Cairo Genizah. Vol. 2, The Community. Berkeley: University of California Press, 1971.

Grohmann, Adolf. From the World of Arabic Papyri. Cairo: Al-Maaref Press, 1952.

Haines, John. "The Origins of the Musical Staff.” The Musical Quarterly 91.3/4 (2008): 327-78.

Hassan, Ahmad Y. al-, and Donald R. Hill. Islamic Technology: An Illustrated History. Cambridge: Cambridge University Press, 1986.

Hilali, Asma. The Sanaa Palimpsest: The Transmission of the Qur'an in the First Centuries AH. Oxford: Oxford University Press in association with the Institute of Ismaili Studies, 2017.

Howe, Christopher J. and Heather F. Windram. "Phylomemetics - Evolutionary Analysis beyond the Gene.” PLoS Biology 9.5 (2011), doi:10.1371/journal.pbio.1001069.

Ibn al-'Arabī, Abū Bakr. al-'Awāṣim min al-qawāṣim fī taḥī̃ mawāqif al-ṣahāāba. Beirut: Dar al-Kotob al-'Ilmiyah, 2010.

Jeffery, Arthur. Materials for the History of the Text of Qur'ān. The Old Codices, The Kitāb al-Mașāhif of Ibn Abī Dāwūd together With a Collection of the Variant Readings from the 
Codices of Ibn Ma'sūd, Ubai, Alī, Ibn 'Abbās, Anas, Abū Mūsā and other early Qur'ānic authorities which present a type of text anterior to that of the canonical text of 'Uthmān. Leiden: Brill, 1937.

Jones, Alan. "The Dotting Of A Script And The Dating Of An Era: The Strange Neglect Of PERF 558." Islamic Culture 72.4 (1998): 95-103.

Kaplony, Andreas. "What are those Few Dots for? Thoughts on the Orthography of the Qurra Papyri (709-710), the Khurasan Parchments (755-777) and the Inscription of the Jerusalem Dome of the Rock (692).” Arabica 55 (2008): 91-112.

Kaplony, Andreas and Michael Marx, eds. Qur'ān Quotations Preserved on Papyrus Documents, 7th-10th Centuries And the Problem of Carbon Dating Early Qur'āns. Leiden: Brill, 2019.

Khan, Geoffrey. Arabic Papyri: Selected Material from the Khalili Collection. London and Oxford: The Nour Foundation, Azimuth Editions and Oxford University Press, 1992.

Kiraz, George Anton. The Syriac Dot: A Short History. Piscataway, NJ: Gorgias Press, 2015.

McGann, Jerome. “Coda: Why Digital Textual Scholarship Matters; Or, Philology in a New Key.” In The Cambridge Companion to Textual Scholarship, edited by Neil Fraistat and Julia Flanders, 274-88. Cambridge: Cambridge University Press, 2013.

McKenzie, Donald Francis. Bibliography and the Sociology of Texts. Cambridge: Cambridge University Press, 2009 [1999].

Monella, Paolo. "Many Witnesses, Many Layers: The Digital Scholarly Edition of the Iudicium Coci et Pistoris (Anth. Lat. 199 Riese)." In Digital Humanities: Progetti Italiani Ed Esperienze Di Convergenza Multidisciplinare, Atti Del Convegno Annuale Dell'Associazione per l'Informatica Umanistica e La Cultura Digitale (AIUCD) Firenze, 13-14 Dicembre 2012, edited by Fabio Ciotti, 173-206. Roma: Sapienza Università Editrice, 2014.

Mordenti, Raul. "Parádosis. A proposito del testo informatico." Atti della Accademia Nazionale dei Lincei. Classe di Scienze Morali, Storiche e Filologiche. Memorie, Serie IX, 28.4 (2011): 623-91.

Mostafa, Mostafa G.M., and Ibrahim M. Ibrahim. "Securing the Digital Script of the Holy Quran on the Internet." In Proceedings of 2013 Taibah University International Conference on Advances in Information Technology for the Holy Quran and Its Sciences, NOORIC 2013, edited by Juan E. Guerrero, 57-60. Piscataway, NJ: The Institute of Electrical and Electronics Engineers, Inc., Conference Publishing Service, IEEE Service Center, 2015.

Muehlhaeusler, Mark. “Additional Reading Marks in Kufic Manuscripts.” JIS 27 (2016): 1-16.

Nasser, Shady Hekmat. The Transmission of the Variant Readings of the Qur'ān. The Problem of Tawātur and the Emergence of Shawādhdh. Leiden: Brill, 2013.

Nuovo, Angela. Alessandro Paganino (1509-1538). Padova: Editrice Antenore, 1990.

Ory, Solange. "Un nouveau type de muṣhaf : inventaire des corans en rouleaux de provenance damascaine, conservés à Istanbul." Revue des Etudes Islamiques 33 (1965/ 1966): 87-149.

Parker, David C. An Introduction to the New Testament Manuscripts and Their Texts. Cambridge: Cambridge University Press, 2008.

Parker, David C. Textual Scholarship and the Making of the New Testament. Oxford: Oxford University Press, 2012.

Pierazzo, Elena. "Digital Documentary Editions and the Others." Scholarly Editing: The Annual of the Association for Documentary Editing 35 (2014): 1-23.

Raymond, Darrell, R. Frank Wm. Tompa, and Derick Wood. “Markup Reconsidered.” Technical Report presented at The First International Workshop on Principles of Document Processing, Washington, D.C., October 21-23, 1992: 1-20. 
Sabbah, Thabit, and Ali Selamat. "A Framework for Quranic Verses Authenticity Detection in Online Forum." In Proceedings of 2013 Taibah University International Conference on Advances in Information Technology for the Holy Quran and Its Sciences, NOORIC 2013, edited by Juan E. Guerrero, 6-11. Piscataway, NJ: The Institute of Electrical and Electronics Engineers, Inc., Conference Publishing Service, IEEE Service Center, 2015.

Saleh, Walid A. "The Gloss as Intellectual History: The Ḥāshiyahs on al-Kashshāf." Oriens 41 (2013): 217-59.

Schmidt, Desmond Allan. "Using Stand off Properties for Marking-up Historical Documents in the Humanities." Information Technology 58.2 (2016): 63-69.

Schmidt, Desmond, and Robert Colomb. "A Data Structure for Representing Multi-Version Texts Online." International Journal of Human - Computer Studies 67 (2009): 497-514.

Schmidt, Desmond. "The Role of Markup in the Digital Humanities." Historical Social Research 37 (2012): 125-46.

Schmidt, Thomas. "Greek Palimpsest Papyri: Some Open Questions.” In Proceedings of the 24th International Congress of Papyrology, Helsinki 1-7 August 2004, edited by Jaakko Frösén, Tiina Purola and Erja Salmenkivi, vol. 2, 979-90. Helsinki: Societas Scientiarum Fennica, 2007.

Segre, Cesare. Semiotica filologica. Testo e modelli culturali. Torino: Giulio Einaudi editore, 1979.

Shatzmiller, Maya. Labour in the Medieval Islamic World. Leiden: Brill, 1994.

Sperberg-McQueen, C. Michael, Claus Huitfeldt, and Allen Renear. "Meaning and Interpretation of Markup." Markup Languages: Theory \& Practice 2.3 (2000): 215-34.

Spitaler, Anton. Die Verszählung des Koran nach islamischer Überlieferung. Sitzungsberichte der Bayerischen Akademie der Wissenschaften: Philosophisch-historische Abteilung 11. München: Verlag der Bayerischen Akademie der Wissenschaften, 1935.

Walker, Jonathan. "Reading Materiality: The Literary Critical Treatment of Physical Texts." Renaissance Drama 41 (2013): 199-232.

Wilson, Brett M. Translating the Qur'an in an Age of Nationalism: Print Culture and Modern Islam in Turkey. Oxford: Oxford University Press in association with The Institute of Ismaili Studies, 2014.

Zayaruznaya, Anna. "In Defense of Green Lines, or The Notation of B-flat in Early Ambrosian Antiphoners." In Ambrosiana at Harvard: New Sources of Milanese Chant, edited by Thomas Forrest Kelly and Matthew Mugmon, 33-56. Cambridge, MA: Houghton Library of the Harvard College Library, 2010. 
